УАK 342.5

ББК 67.400 .6

DOI 10.22394/1682-2358-2020-4-39-47

A.P. Chervinskaya, Candidate of Sciences (Law), Docent of the constitutional and municipal law Department, Central Russian Institute of Management, Branch of the Russian Presidential Academy of National Economy and Public Administration

\section{CRITERIA \\ FOR DIFFERENTIATING BYLAW COMPETENCE BETWEEN \\ THE CHAMBERS \\ OF THE FEDERAL ASSEMBLY \\ OF THE RUSSIAN FEDERATION}

Authorial theoretical and methodological approach to the study of the subordinate competence differentiation mechanism of a Federal state Parliament chambers is proposed. It consists in identifying constitutional criteria for the division of competence between the chambers of the Federal Parliament. These criteria include differentiation of personnel powers, resolution of national security issues, as well as other powers (the right to Amnesty, the right to cancel and suspend regional and local legal acts).

Key words and word-combinations: bylaw competence, powers, Parliament.
А.П. ЧерВинская, кандидат юридических наук, дочент кафедри конституиионного и муниципального праља Среднерусского института управления - филиала Российской академии народного хозяйства и гогударственной службь nри Президенте РФ (email: sasha.m-87@mail.ru)

\section{КРИТЕРИИ РАЗГРАНИЧЕНИЯ ПОАЗАКОННОЙ КОМПЕТЕНЦИИ МЕЖАУ ПАААТАМИ ФЕАЕРААЬНОГО СОБРАНИЯ РОССИЙСКОЙ ФЕАЕРАЦИИ}

Аннотациия. Предлагается авторский теоретико-методологический подход к исследованию механизма разграничения подзаконной компетенции палат парламента федеративного государства. Он заключается в выявлении конституционных критериев разграничения компетенции между палатами федерального парламента. К таким критериям автор относит разграничение кадровых полномочий, разрешение вопросов национальной безопасности, а также иные полномочия (право на амнистию, право отмены и приостановления действия региональных и местных правовых актов).

Ключевые слова и словосочетания: подзаконная компетенция, полномочие, парламент.

$\mathrm{O}$ пыт России и зарубежных стран показывает, что между паматами бикамерамьного парламента Аолжны быть четко разграничены компетенции. Это затрагивает не столько область законодатемьной деятемь- 
ности народного представительства, сколько парламентскую деятельность вне законодательного процесса. Полагаем, что основная цель разграничения компетенции между палатами парламента вне законодательного проџесса заключается в обеспечении возможности конкурировать с оппонентами за вцастные полномочия. Тем самым создаются Аополнительные гарантии реализации принџипа разделения властей.

Анализируя опыт американского конституционацизма по замыслу его «отцов-основателей», Т. Ремингтон подчеркивает необходимость «ограничения возможностей мюбой инстанџии или ветви власти выходить за рамки своих полномочий», не Аопуская превышения вмасти, что Аолжно «подталкивать разАичные составцяющие государства к компромиссу и сотрудничеству Аруг с Аругом» [1, с. 70]. А.Х. Султанов, опираясь на исторический опыт организации двухпалатных парламентов в зарубежных странах, выдвинул тезис о необходимости «бикамерамьного соревнования» [2, с. 111], подразумевая под этим главным образом законодательный процесс. На наш взгляд, это справеАливо и в отношении разграничения подзаконной компетенции палат парламентов.

В.В. Аисов выделяет такие принџипы деятельности государственного аппарата, как пубцичность, социальная направленность, властный характер, всеобщность и непрерывность [3, с. 9]. Разграничение компетенции межАу палатами парламента должно отвечать всем указанным критериям, чтобы гарантировацась конституционность механизма разграничения. ОАнако не менее важные цели анализируемого процесса заключаются, на наш взглял, в достижении сбалансированности, а в условиях федеративной формы политико-территориального устройства государства - также учета потребностей и интересов субъектов федеративного государства.

Рассуждая о целесообразности второй палаты, О.Н. Булаков солидарен с известным французским государствоведом М. Прело в том, что «только в федеративных государствах бикамерацьное устройство имеет естественную природу» [4, с. 100]. В связи с этим подзаконная компетенция Совета Федерации Федерального Собрания Российской Федерации (далее - Совет Федерации) прежке всего должна отражкать федеративную форму Российского государства. Однако В.М. Сайфудаинова верно подмечает, что полномочия Совета Федераџии в своем большинстве не связаны с реализаџией потребностей и интересов субъектов Российской Федерации. Исключение составцяет мишь право утвержления изменения граниџ межау субъектами Российской Федерации. В этом, по мнению автора, проявмяется «дуацистичность» статуса пацаты как общенационацьного государственного органа и органа представительства субъектов Российской ФеАерации [5, с. 35-36].

Н.А. Антюшин, на наш взгляА, недостаточно точно квацифицирует внезаконодательную компетенцию Совета Федерации как его «контрольные полномочия». Подобная терминология не вполне верна с конституционно-правовой точки зрения, так как термин «парламентский контроль» имеет более узкое смысловое значение, подразумевая интерпемляцию, импичмент, вотум неАоверия, резолющии порицания и парламентские расследования. ОАнако следует 
признать, что контрольные полномочия парламента сами по себе имеют внезаконодательную природу, так как они не связаны с полномочиями памат парламента в законодательном процессе. Автор анацизируемого исследования разграничивает законодательные полномочия Совета Федераџии как «контролера», а Государственной Аумы - как «разработчика» законодательства [6, с. 128-129].

Вызывает интерес предложенная А.С. Покровским классификация «внезаконодательных» полномочий палат парламентов при бикамеральной структуре народного представительства, основанная на критерии «степени эгалитарности». Автор считает, что Авухпалатность может быть эгацитарной, ограниченно эгалитарной и совсем не эгалитарной; вслед за этим якобы дифференџируются внезаконодательные полномочия палат парламента [7, с. 136-137].

Критический анализ приведенных точек зрения позволяет предложить авторский теоретико-методологический подход к исследованию механизма разграничения подзаконной компетенции палат парламента федеративного государства. Он закцючается в выявлении конституционных критериев разграничения компетенции между палатами.

Первый критерий, по нашему мнению, состоит в разграничении каАровых полномочий (назначение на Аолжности и освобожАение от Аолжностей). Опыт России и зарубежных стран доказывает, что в этой сфере разграничение компетенции палат выглядит наиболее существенным. Конституционная реформа 2020 г. [8, ст. 1416] также не обошиа стороной этот процесс: Президентом Российской Федераџии было преАложено, с оАной стороны, усицение влияния Государственной Аумы на формирование состава Правительства Российской Федераџии, с Аругой стороны, ограничение ряда кадровых полномочий Совета Федераџии (в частности, Ао конституционной реформы 2020 г. правом назначения Генерального прокурора Российской Федерации обладал Совет Федерации, что приводицо к спорам о компетенции межху Президентом Российской Федерации и парламентом[9]; конституционная реформа 2020 г. закрепила Аанную прерогативу за главой государства, искмючая решающее парламентское вцияние на процессы назначения и освобождение от Аолжности Генерального прокурора страны). Обновленное конституционное регулирование разграничения кадровых полномочий межАу Президентом Российской Федераџии и палатами Федерацьного Собрания получицо положительную оџенку Конституџионного СуАа Российской Федераџии с точки зрения соответствия первым Авум главам Конституции страны [10] .

Основное кадровое полномочие Государственной Аумы состоит в праве участия в назначении состава Правительства Российской Федерации. Ао конституционной реформы 2020 г. оно ограничивалось правом троекратного согласования кандидатуры Председателя Правительства Российской Федерации, причем в довольно усеченном виде (Президент Российской Федерации в свое время прибегал к практике внесения одной и той же кандидатуры, что не вызвало возражений Конституционного Суда Российской Федерации) [11] . Посме конституционной реформы 2020 г. подавляющее большинство федераль- 
ных министров (за исключением министров, подведомственных Президенту Российской Федерации), Аолжно формироваться на основе волеизъявления депутатов Государственной Аумы. Председатель Правительства Российской Федерации назначается Президентом Российской Федерации, кандидатура которого должна быть утверждена Государственной Аумой. Особо стоит отметить, что народные избранники голосуют не за политическую программу, предложенную кандидатом на должность Председателя Правительства Российской Федерации, а за самого кандидата, что способствует персонацизации каАрового решения.

КаАровые полномочия палат Федерального Собрания не исчерпываются назначением или согласованием назначения членов Правительства Российской Федерации. Так, Совет Федерации назначает и освобождает от должности судей Конституџионного Суда Российской Федераџии и Верховного Суда Российской Федерации. Палаты участвуют в назначении должностных миџ и ауАиторов Счетной палаты Российской Федераџии, председателя Центрального банка Российской Федерации, чценов Центральной избирательной комиссии Российской Федераџии и т.А. - в сущности, практически всех должностных миџ, которые не входят в «классическую триаду» разделения властей на законодательную, исполнительную и судебную ветви власти. Если компетенция по назначению этих должностных миџ переходит в состав полномочий Президента Российской Федерации, минуя волю палат парламента (вследствие конститущионной реформы 2020 г. это произошло, в частности, в механизме назначения и прекращения полномочий Генерального прокурора Российской Федерации) - наблюдается отклонение от требуемого ст. 10 Конституџии Российской Федерации баланса властных полномочий высших государственных органов страны. В целом полномочия Президента Российской Федерации в части каАровых вопросов, на наш взгляА, значительным образом сбалансированы компетенцией палат Федерального Собрания, причем и Совет Федерации, и Государственная Аума Федерального Собрания Российской Федераџии примерно в равной пропорџии обцадают соответствующими кадровыми полномочиями.

В контексте анализа кадровых полномочий палат Федерального Собрания особо стоит рассмотреть вопрос допустимости установления прерогатив на Аосрочное прекращение полномочий их членов.

В 2012 г. в Конституџионном Суде Российской Федерации слушалось Аело о проверке конституционности Федерацьного закона о статусе сенаторов и федеральных депутатов в части проверки допустимости установления прерогатив палат Федерального Собрания на досрочное прекращение полномочий их чменов. Полагаем, что это весьма значимое явление российского конституџионализма, которому в свое время не уделямось наАлежащего внимания в научной и публицистической митературе. Прежде всего важно подчеркнуть, что Конституџия Российской Федераџии не наделяет Совет Федерации правом досрочного прекращения полномочий сенаторов Российской Федераџии, равно как и Государственную Ауму прерогативой кишения ее депутатов народного мандата. В течение сравнительно продолжительного 
времени после принятия Конституции Российской Федерации 1993 г. считалось очевидной в силу конституџионного обычая недопустимость такого расширения компетенџии палат вне законодательного процесса. Совет ФеАераџии и Государственную Ауму можно наделить мюбым разумным каАровым полномочием подзаконного характера, но не компетенцией, фактически заменяющей волеизъявление формирующих состав палат субъектов конституционных правоотношений. Надемение Совета Федераџии правом досрочного прекращения полномочий федеральных сенаторов означало бы не просто подмену права законодательных (представительных) и исполнительных органов субъектов Российской Федераџии на формирование и отзыв своих преАставитемей. Это позволяло бы, пусть и косвенным образом, мажоритарному большинству других субъектов Федерации оказывать доминирующее влияние на кадровую политику каждого конкретного субъекта Российской Федерации. Аналогичный принцип может быть распространен и на проџесс формирования Государственной Аумы: если данная палата Федерального Собрания вправе досрочно прекратить полномочия отдельного депутата, то фактически это означает, что мажоритарное большинство парламентариев вправе контролировать деятельность отдельного депутата, который преАставмяет соответствующий эмекторат и вправе рассчитывать на известную степень независимости в политической деятельности. Конституџионный Суд Российской Федераџии не посчитал это нарушением Конституџии Российской Федераџии, если не принимать во внимание ряд не заслуживающих внимания деталей конституџионно-правового регулирования. Мотивировалось это наличием конституџионной дискреџии законодателя, разнообразием практики зарубежных стран, квазисудебной проџедурой рассмотрения соответствующих дел в Государственной Ауме и возможностью последуюшего судебного контроля Аосрочного прекрашения полномочий депутата в судах общей юрисдикщии [12] .

Второй критерий в механизме разграничения полномочий межАу палатами парламента, на наш взгляА, состоит в разрешении вопросов наџиональной безопасности, включая вопросы войны, мира, введения режимов чрезвычайного и военного положения, режима контртеррористической операџии. Значимость данной функщии прослеживается при анализе практики Конститущионного Суда Российской Федерации, вытекающей из споров о компетенции, Ааже если дело рассматриванось Судом в проџедуре проверки конституџионности оспариваемого акта по порядку его принятия. Так, в 1995 г. в Конституџионном Суде Российской Федераџии по иниџиативе группы парламентариев и самого Совета Федерации рассматривалось дело о конституџионности решения главы государства об использовании вооруженной силы в Чеченской Республике, минуя волю парламента. СуА признал правомерность действий Президента Российской Федераџии, так как наличие пробелов в законодательстве повышают значимость прямого действия Конституции Российской Федерации [13].

Конституция Российской Федерации относит к ведению Совета Федераџии три полномочия в анализируемой сфере: «утверждение» президент- 
ских указов о введении военного и чрезвычайного положений, а также «решение вопроса о возможности использования» Вооруженных Сиц за пределами территории России [14] . Режимы военного и чрезвычайного поможения преАусмотрены непосредственно Конституцией Российской ФеАерации, как и требование о необходимости принятия соответствующих федеральных конституџионных законов. ОАнако сама Конституџия Российской Федерации разграничима компетенцию Президента Российской Федерации и палат парламента таким образом, что, во-первых, Государственная Аума в процессе участия не принимает; во-вторых, Президент Российской Федерации издает указы о введении военного или чрезвычайного положения; в-третьих, Совет Федерации данные указы вправе утвердить кибо отказать в их утверждении.

Примечательно, что Федеральный конституционный закон «О чрезвычайном положении» позвоцяет Президенту Российской Федерации не просто самостоятельно принять решение о введении данного режима, но также фактически ввести его после обнародования соответствующего указа Амя всеобщего сведения. Совет Федераџии обязан собраться на заседание без специального вызова в кратчайшие сроки. Отказ Совета Федерации от утверждения указа Президента Российской Федерации о чрезвычайном положении отменяет этот режим мишь по истечении 72 часов с момента его обнародования [15, ст. 7]. Нормы ст. 4 Федерального конституционного закона «О военном положении» аналогичны, если не считать сокращенные сроки аннулирования Аействия указа Президента Российской Федерации (Аействие прекращается со следующего Аня и не требует истечения 72 часов) [16]. При таком правовом регулировании глава государства обладает существенной Аискрецией, которая фактически позволяет ему ввести краткосрочный режим без согласия Аанной палаты парламента. Неопределенность правового регулирования усимивается достаточно спорным методом «самостоятельного сбора» сенаторов Российской Федерации без специальных организационных действий со стороны руководства и аппарата Совета Федерации, что на практике выглядит труднореализуемым.

Некоторые вопросы разграничения подзаконной компетенџии межАу пацатами парламента с трудом подАаются научной классификаџии, в связи с чем их удобно именовать «иными». Это обусловлено единичным характером соответствующей компетенџии (почему она и не подпадает под критерии соответствующей кцассификации). Так, в Конституционном Суде Российской Федераџии в 1997 г. слушалось дело о допустимости толкования федеральных законов постановлением Государственной Аумы. СуА признал это противоречащим Конституции страны [17] .

Право Государственной Аумы на амнистию осужденных по своей природе является единичной прерогативой, которая не может быть отнесена к какой-цибо группе полномочий палат Федерацьного Собрания. Это обусмовцено уголовно-правовым характером компетенции Государственной Аумы, в то время как по общему правицу палаты Федерацьного Собрания субъектами уголовного процесса не явцяются. Тем не менее даже в этой 
сфере возникают отдельные споры конституционно-правового характера. В частности, Конституџионный СуА Российской Федераџии признал недопустимым поворот к худшему в подзаконном правовом акте Государственной Аумы об амнистии [18]. При этом амнистия не препятствует суау рассмотреть уголовное дело по существу и лишь затем применить акт палаты парламента об амнистии - этот вывод Конституџионного Суда Российской Федераџии, касающийся разграничения полномочий парламента и судов общей юрисдикщии, также имел конститущионно-правовую природу, несмотря на первичность проблематики уголовно-процессуального характера [19] .

Российский конституционный законодатель, на наш взгляА, преследовал верную конституционную џель «равномерного» разграничения компетенции палат парламента, а также обособления этой компетенџии от прерогатив Президента Российской Федерации и Правительства Российской Федерации. С этой точки зрения анализируемые нормы Конституџии Российской Федераџии соответствуют общепризнанному принџипу раздемения властей.

ОАнако вопросы об освобождении от уголовной ответственности (инАивидуально в форме помицования и применительно к категориям миџ посредством амнистии), по нашему мнению, явцяются слишком важными, чтобы находиться в компетенции какого-либо одного органа или должностного кица. Это не вполне соответствует принџипу верховенства уголовного закона, исключения из которого фактически допускаются в форме подзаконных актов (указов Президента Российской Федерации и постановлений Государственной Аумы). Кроме того, полагаем, что вопросы амнистии и помилования должны решаться в форме закона, а не посредством подзаконного акта.

Право отмены и приостановления действия правовых актов региональных и местных народных избранников, на наш взгляд, является единичной компетенџией и характерно для ряда зарубежных стран (таким правом обладает Совет Национального Собрания Республики Беларусь).

В России данная компетенция не принадлежит ни Совету Федерации, ни Государственной Ауме, ни Президенту Российской Федераџии, ни кому-либо еще, включая судебные инстанции. Российская доктрина и практика исходят из презумпции, что акты органов народного представительства могут быть отменены кишь самими органами, их издавшими. СуА вправе признать акт органа народного представительства противоречашим законодательству, потому не подмежашим применению. При определенных обстоятельствах невыполнение судебного решения может привести к досрочному прекращению полномочий органа народного представительства. ОАнако право отмены актов «вышестояшим» органам власти не принадмежит по причине отсутствия «еАиной системы» преАставительной власти.

Вместе с тем в России имеется практика отмены и приостановцения действия правовых актов в единой системе исполнительной власти. Так, Президент Российской Федераџии вправе отменить решение Правительства 
Российской Федерации и приостановить действие правового акта исполнительного органа субъекта Российской Федерации. Этому противопоставмяется модель правового регулирования, согласно которой Федеральное Собрание в целом и его палаты не обладают полномочием нормоконтроця в отношении деятельности законодательных (представительных) органов субъектов Российской Федерации, тем более - представительных органов муниципальных образований.

На наш взгляА, идея конституционного принципа разделения властей состоит в том, чтобы каждый орган самостоятельно осушествАя компетенцию и никто в эту компетенџию не вмешивался бы. Можно утверждать, что в современной России признается принцип разделения властей в отношении законодательной, исполнительной и судебной ветвей власти, но он отрицается, когАа речь идет о единой системе исполнительной власти (компетенция Президента Российской Федерации, Правительства Российской Федерации, а также федеральных министерств, агентств и служб разграничена не полностью, потому что вышестоящей инстанции дозволяется отменять решения нижестоящих органов).

На основании изможенного можно сформулировать следующий вывод. Анализ практики конституционного регулирования России показывает, что компетенция палат Авухпалатного парламента не исчерпывается законодательной процедурой. Как правило, палаты наделяются дополнительными индивиАуальными полномочиями, что может предусматриваться как в Конститущии страны, так и в законодательных актах, которые конкретизируют принципы и иные конституционные установмения.

\section{Библиографический список}

1. Ремингтон T. Бикамерализм и Совет Федерации России // Конституционное право: восточноевропейское обозрение. 2003. № 3.

2. Султанов А.Х. Национальные особенности парламентаризма в Англии (историко-правовой аспект) // Правовое государство: проблемы понимания и реализации. Уфа, 2015. Т. 1.

3. Лисов В.В. Ограничения конституционных прав граждан, связанные с поступлением на государственную службу Российской Федерации и ее прохождением: автореф. дис. ... канд. юрид. наук. Саратов, 2014.

4. Булаков О.Н. Бикамерализм как структурная организация современного парламента // PolitBook. 2013. № 3.

5. Сайфутдинова В.М. Совет Федерации Федерального Собрания: специфика и перспективы // Актуальные проблемы российского права. 2017. № 8.

6. Антюшин Н.А. Роль «верхних» палат в бикамеральных парламентах в укреплении парламентаризма в условиях обновления их состава (на примере России, Казахстана и Франции) // Ойкумена: Регионоведческие исследования. 2019. № 3.

7. Покровский Д.С. Внешнеполитические полномочия верхних палат парламентов зарубежных стран // Власть. 2009. № 5.

8. О совершенствовании регулирования отдельных вопросов организации и функционирования публичной власти: Закон РФ о поправке к Конституции РФ от 14 марта 2020 г. № 1-ФКЗ // СЗ РФ. 2020. № 11.

9. По спору о компетенции между Советом Федерации и Президентом Российской Федерации относительно принадлежности полномочия по изданию акта о временном отстранении 
Генерального прокурора Российской Федерации от должности в связи с возбуждением в отношении него уголовного дела: постановление Конституционного Суда РФ от 1 дек. 1999 г. № 17-П // СЗ РФ. 1999. № 51. Ст. 6364.

10. О соответствии положениям глав 1,2 и 9 Конституции Российской Федерации не вступивших в силу положений Закона Российской Федерации о поправке к Конституции Российской Федерации «О совершенствовании регулирования отдельных вопросов организации и функционирования публичной власти», а также о соответствии Конституции Российской Федерации порядка вступления в силу статьи 1 данного Закона в связи с запросом Президента Российской Федерации: заключение Конституционного Суда РФ от 16 марта 2020 г. № 1-3 // Российская газета. 2020. 17 марта.

11. По делу о толковании положений части 4 статьи 111 Конституции Российской Федерации: постановление Конституционного Суда РФ от 11 дек. 1998 г. № 28-П // СЗ РФ. 1998. № 52 . Ст. 6447.

12. По делу о проверке конституционности положений пункта «в» части первой и части пятой статьи 4 Федерального закона «О статусе члена Совета Федерации и статусе депутата Государственной Думы Федерального Собрания Российской Федерации» в связи с запросом группы депутатов Государственной Думы: постановление Конституционного Суда РФ от 27 дек. 2012 г. № 34-П // С3 РФ. 2013. № 1. Ст. 78.

13. По делу о проверке конституционности Указа Президента Российской Федерации от 30 ноября 1994 года № 2137 «О мероприятиях по восстановлению конституционной законности и правопорядка на территории Чеченской Республики)», Указа Президента Российской Федерации от 9 декабря 1994 года № 2166 «О мерах по пресечению деятельности незаконных вооруженных формирований на территории Чеченской Республики и в зоне осетино-ингушского конфликта»: постановление Конституционного Суда РФ от 31 июля 1995 г. № 10-П. URL: www.consultant.ru/document/cons_doc_LAW_7552

14. Об использовании Вооруженных Сил Российской Федерации за пределами территории Российской Федерации: постановление Совета Федерации от 30 сент. 2015 г. № 355-СФ // С3 РФ. 2015. № 40. Ст. 5469.

15. О чрезвычайном положении: Федеральный конституционный закон от 30 мая 2001 г. № 3-ФКЗ // СЗ РФ. 2001. № 23. Ст. 2277.

16. О военном положении: Федеральный конституционный закон от 30 янв. 2002 г. № 1-ФК3 // С3 РФ. 2002. № 5. Ст. 375.

17. По делу о проверке конституционности постановлений Государственной Думы Федерального Собрания Российской Федерации от 21 июля 1995 года № 1090-І ГД «О некоторых вопросах применения Федерального закона «О внесении изменений и дополнений в Закон Российской Федерации «О статусе судей в Российской Федерации» и от 11 октября 1996 года № 682-II ГД «О порядке применения пункта 2 статьи 855 Гражданского кодекса Российской Федерации: постановление Конституционного Суда РФ от 17 нояб. 1997 г. № 17-П // СЗ РФ. 1997. № 47. Ст. 5492.

18. По делу о проверке конституционности постановления Государственной Думы от 28 июня 2000 года № 492-III ГД «О внесении изменения в постановление Государственной Думы Федерального Собрания Российской Федерации «Об объявлении амнистии в связи с 55-летием Победы в Великой Отечественной войне 1941-1945 годов» в связи с запросом Советского районного суда города Челябинска и жалобами ряда граждан: постановление Конституционного Суда РФ от 5 июля 2001 г. № 11-П // СЗ РФ. 2001. № 29. Ст. 3059.

19. По делу о проверке конституционности положения пункта 8 постановления Государственной Думы от 26 мая 2000 года «Об объявлении амнистии в связи с 55 -летием Победы в Великой Отечественной войне 1941-1945 годов» в связи с жалобой гражданки Л.М.Запорожец: постановление Конституционного Суда РФ от 24 апр. 2003 г. № 7-П // СЗ РФ. 2003. № 18. Ст. 1748. 